\title{
Counterfeit Product
}

National Cancer Institute

\section{Source}

National Cancer Institute. Counterfeit Product. NCI Thesaurus. Code C121834.

A product has been determined to be counterfeit. 